\title{
An Exceptional Exclamative Sentence Type in Romance*
}

\author{
Xavier Villalba \\ Universitat Autònoma de Barcelona \\ Departament de Filologia Catalana \\ Facultat de Lletres. Edifici B \\ 08193 Bellaterra (Barcelona). Catalonia (Spain) \\ Xavier.Villalba@,uab.es
}

\section{Abstract}

The main hypothesis of this paper is that certain exclamative constructions in Catalan (queexclamatives) involve a null exclamative degree operator. It is shown that, when combined with Kayne's (2002) insights concerning English preposition of and its French counterpart de, a principled and unified explanation follows not only for que-exclamatives but for the related com-exclamatives as well. Empirical and theoretical arguments are provided for deriving the presence of the marker de ('of') as a VP-external preposition from the existence of a quantificational structure, and that of the partitive clitic en/ne from the necessity of providing the null exclamative operator with a content.

Key words: degree modification, exclamative sentence, null operator, preposition de, rightdislocation, sentence type

Among non-declarative sentence types, exclamatives have received considerably less attention than interrogatives in Romance linguistics, and very often even the otherwise highly detailed descriptive grammars tend to get rid of them with a cursory comment in the chapter devoted to the interrogative sentence type. Fortunately, since the pioneering studies in the late seventies and the eighties (Milner 1978 and Gérard 1980 for French, Bosque 1984 for Spanish, and Radford 1982 and Benincà 1988 for Italian, among others), our current understanding of the exclamative type in Romance has been broadened considerably by the works by Benincà (1995), and Zanuttini \& Portner (2000, 2001). The main goal of the present paper is to contribute to this effort, bringing new data to the fore, namely those of an

\footnotetext{
${ }^{*}$ I am most grateful to Anna Bartra, Albert Fontich, Eva Monrós, Sílvia Planas i Morales, Paul Portner, and Joan Solà for comments. None of them is, however, responsible of any of the shortcomings in this article. This research has been supported by the grants 1999SGR 00113 (Generalitat de Catalunya), 2000 XT00032
} 
exclamative construction in Catalan (henceforth que-exclamative), which shows noteworthy syntactic features without strict parallel — to my knowledge - in the Romance panorama. ${ }^{1}$ The following data illustrate the point: ${ }^{2}$

(1) a. ¡Ai, filla, que en vas, d'equivocada! (Solà 1990: ex. 18f)

alas daughter that of.it go.2 of-mistaken

'Oh, dear, how wrong you are!'

b. ¡Que n'és, de car! (Solà 1999: ex. 2) ${ }^{3}$

that of.it-is of expensive

'How expensive it is!'

Despite the lack of (overt) wh-element, sentences in (1) are systematically interpreted by native speakers as virtually synonymous of the typical $w h$-exclamatives in (2):

(2) a. Ai, filla, que equivocada que vas!

alas daughter how mistaken that go.2

'Oh, dear, how wrong you are!'

b. Que car que és!

how expensive that is

'How expensive it is!'

(Generalitat de Catalunya), and BFF2000-0403-C02-01 (Ministerio de Ciencia y Tecnología) awarded to the Grup de Gramàtica Teòrica of the Universitat Autònoma de Barcelona.

${ }^{1}$ French has a kindred construction, but lacking marker de (Gérard 1980: ex. 64):

(i) Qu'il est gentil!

that-he is kind

'How kind he is!'

Italian and Spanish, instead, lack any related equivalent.

${ }^{2}$ In Solà's examples, I respect his typographic conventions, namely the use of opening exclamative sign and that of the comma separating the adjective from the rest of the sentence, but I provide the sentences with a gloss and a translation. The conventions regarding the glosses of the examples are the following: FUT $=$ future, LOC $=$ locative clitic, $\mathrm{NEG}=$ negation, $\mathrm{NEUT}=$ neuter, $\mathrm{PL}=$ plural, $\mathrm{SUB}=$ subjunctive. Moreover, for the ease of exposition, I will conventionally mark the relationship between right-dislocates and their pronominal correlates within the sentence by means of a subscript.

${ }^{3}$ The sentence may also be introduced by mans of the intensive particle $s i$ 'so', which must carefully be distinguished from the affirmative particle si 'yes':

(i) ¡Si que n'és, de car! (Solà 1999: ex. 3)

so that of.it-is of expensive

'How expensive it is!'

See Mariner (1979) and Solà (1999) for details. 
This clearly perceived synonymy gives rise to interesting theoretical and empirical questions. First of all, it must be stated whether que-exclamatives should be considered proper exclamative sentences or rather a non-exclamative sentence type conveying the illocutionary force of an exclamation, such as the following sentence:

\section{(3) Aquest vi és caríssim!}

this wine is very.expensive

'This wine is very expensive.'

As Zanuttini \& Portner (2001) point out, failure to properly distinguish the illocutionary force of a sentence from its type has blurred the typology of constructions displaying the exclamative type. Hence, our first goal will consist in confirm the speakers' intuition that queexclamatives are fully-fledged exclamative sentences. This task will be conducted in section 1.

Once this point will be properly settled, the attention will shift to the syntactic features that make these examples interesting for anyone attempting a better understanding of the mechanisms underlying the expression of the exclamative type in Romance, namely (i) the introduction of the sentence by means of complementizer que 'that', (ii) the presence of the partitive clitic en/ne, and (iii) the introduction of the adjective by means of the marker de ('of'). Since que-exclamatives are very partially described in Catalan grammar literature, a finer-grained characterization of the construction will be provided with the intention of broadening and refining the typology of Romance exclamative sentences. The developing of this descriptive effort will occupy section 2.

Finally, an analysis of que-exclamatives will be offered deriving the exclamative character of the construction from the presence of a null exclamative operator. Crucially, the proposal will benefit from Kayne's (2000, 2001, 2002) insights concerning English preposition of and its French counterpart de as heads merging outside the VP. The combination of both aspects will offer a proper explanation for otherwise intractable syntactic properties.

\section{Tests for the exclamative type}

Part of the scarce literature on exclamatives (Elliott 1974, Grimshaw 1979, Bosque 1984, Zanuttini \& Portner 2000, 2001) has dedicated much effort to set a series of standard tests to 
properly identify exclamative sentences, especially in contrast with interrogative ones. In this section, two of these standard tests will be contemplated to show that Catalan queexclamatives in (1) belong to the exclamative sentence type in all the relevant respects.

\subsection{Factivity}

Elliott (1974) observed that exclamatives clauses are inherently factive, so that they can only be embedded under factive predicates (see also Grimshaw 1979). Henceforth, since the addition of the modifier very forces the exclamative reading, the following contrast arises:

(4) a. It's amazing how very expensive this wine is.

b. *I asked how very expensive this wine was.

In (4)b, the semantics of the exclamative construction, which presupposes the truth of the proposition it denotes, is at odds with that of the predicate, which in both cases presupposes ignorance concerning the validity of the denoted proposition. This conflict leads to the contrast between (4)a and (4)b.

Unfortunately, this test cannot be applied to que-exclamatives, which only appear in root contexts. ${ }^{4}$ Yet, the inherently factive character of the construction reveals itself clearly under appropriate conditions, as in the following dialogue:

(5) A: La Maria té un màster de Harvard. the Maria has a master of Harvard 'Maria obtained a master degree from Harvard.'

B: Caram, que n'és d'intel-ligent! \#Si és que ho és. boy that of.it-be of-intelligent if is that it is 'Oh, boy, how intelligent she is! \#If she is intelligent at all.'

${ }^{4}$ Only two cases of embedded que-exclamatives can be attested in Catalan grammatical literature:

(i) a. No pots afigurar-te que n'era, de babau. Ruaix (1975: 54) not can. 2 reckon that of.it-was of fool 'You can't reckon how foolish (s)he was.'

b. ¡Mira que n’arriba a ser, de talós! Solà (1994a: § 3.4) look that of.it-arrives to be of stupid 'Note how stupid (s)he was.' 
As the translation shows, the state of ignorance introduced by the continuation in B's response is incompatible with the presupposition carried by the exclamative construction that Mary is intelligent, rendering B's response unfelicitous. It is thus clear that que-exclamatives are inherently factive, just as standard $w h$-exclamatives:

(6) A: La Maria té un màster de Harvard.

the Maria has a master of Harvard

'Maria obtained a master degree from Harvard.'

B: Caram, que intel·ligent que és! \#Si és que ho és.

boy how intelligent that is if is that it is

'Oh, boy, how intelligent she is! \#If she is intelligent at all.'

\subsection{Extreme degree interpretation}

Catalan que-exclamatives express a degree quantification over the scale denoted by the adjective, so that this construction is incompatible with non-gradable adjectives, as becomes apparent in the following paradigm, where the equivalent wh-exclamative is added for convenience:

(7) a. *Aquest gat és molt persa/quadrúpede.

this cat is very Persian/four-legged

b. 'Que n'és de persa/quadrúpede, aquest gat! that of.it is of Persian/four-legged this cat

c. *Que persa/quadrúpede que és aquest gat! that friendly/four-legged that is this cat

Neither persa ('Persian') nor quadrúpede ('four-legged') are gradable adjectives, so we can attribute the illformedness of all the cases in (7) to a case of vacuous quantification (more on this in section 3).

The status of these sentences is unclear, for (ia) is clearly perceived as marginal by speakers, and it is dubious (ib) represents a genuine instance of subordination. Rather, the imperative form of the verb mirar 'see' works as a discourse element fulfilling a phatic function. 
Yet, Zanuttini \& Portner (2001) claim that, in addition to this literal meaning, exclamatives yield a conventional scalar implicature of highest degree (which they characterize in terms of the semantic notion of 'widening', borrowed from Kadmon \& Landman 1993). ${ }^{5}$ Their semantic description extends to que-exclamatives straightforwardly, so that as the sentence in (8)a can be paraphrased as in (8)b:

a. Que n'és de car aquest vi!

that of.it-is of expensive this wine

'How expensive this wine is!'

b. This wine is extremely expensive. / This wine is more expensive than I expected.

Here, the property denoted by the adjective is quantified over a scale, but unlike in normal degree quantification the point is placed somewhere higher than the maximum of the standard scale. Confirmation for this fact follows from the restriction over the modifiers accompanying the adjective in que-exclamatives (noted by Elliott 1974 for wh-exclamatives). Compare the

${ }^{5}$ Portner \& Zanuttini (2001: 11) argue that the highest degree meaning associated with exclamatives must be
considered a conventional scalar implicature under Grice's (1989) typology of implicatures, for it cannot be
canceled (ia) nor is detachable (ib) - the intensive version has an equivalent content, but it lacks the implicature:

(i) a. ??How very cute he is! — though he's not extremely cute.

b. He's quite cute! - though not extremely cute. Portner \& Zanuttini (2001: ex. 13)

Furthermore, Paul Portner (p.c.) correctly points out to me that the implicature at issue can hardly be computable from the interaction of Grice's Cooperative Principle with any conversational maxim, unlike typical scalar conversational implicatures, which arise from apparent violations of the Maxim of Quantity.

Yet, this characterization is controversial, for strong doubts exist concerning the detachability of the implicature under question. Consider the following hidden exclamative construction in Catalan (on hidden exclamatives in Spanish, see 2.6 below):

(ii) Té UNS collons!

has a.PL balls

'(S)he is so cheeky.'

Interestingly, this sentence conveys an implicature of highest degree exactly as exclamatives do, as the impossibility of cancellation shows:

(iii) Té UnS collons! \#Encara que no excessius.

has many balls though that not excessive

'(S)he is so cheeky, even though not that much.'

Yet, since this implicature is not tied to the exclamative form of the sentence, one must conclude that it cannot be a conventional implicature, in any event. The issue merits a more detailed discussion than the one offered here. 
behavior of normalment 'normally' and ordinàriament 'ordinarily' on the one hand with that of extremament 'extremely' and rematadament 'completely' on the other:

(9) a. *Que n'ets de normalment/ordinàriament ximple!

that of.it-are of normally/ordinarily fool

‘*How normally/ordinarily fool you are!'

b. Que n'ets d'extremament/rematadament ximple!

that of.it-are of-extremely/competely fool

'How extremely/completely fool you are!'

Only modifiers denoting excess are compatible with the extreme degree implicature accompanying que-exclamatives.

Taken as a whole, the evidence reviewed in this section strongly supports considering que-exclamatives as true representatives of the exclamative sentence type, as devised in Zanuttini \& Portner (2001).

\section{A previous analysis of que-exclamatives}

Even though extremely vigorous in Catalan, traditional grammarians have paid little attention to que-exclamatives. Indeed, very scarce comments can be gleaned among the few works that even mention them. This section is devoted to filling this gap by means of a detailed description of their major syntactical properties.

As outlined in the introduction, three major features make que-exclamatives worth studying: the introduction of the sentence by means of complementizer que 'that', the presence of the partitive clitic en/ne, and the introduction of the adjective by means of the marker $d e$. Since Catalan is a unique language in requiring the introduction of right-dislocated adjectives by means of a marker $d e$ - formally identical to the preposition de 'of' - the latter pair has traditionally been derived from the claim that the modified adjective is rightdislocated, so that que-exclamatives in (10)a should be analyzed on a pair with the rightdislocation structure in (10)b (see for instance López del Castillo 1999: 37-38, Solà 1999: 232-233, and Wheeler et al. 1999: 498):

(10) a. Que n'ets de ximple! that of.it-are of fool 
'What a fool you are!'

b. Sempre ho ha sigut, de ximple.

always it have. 3 been of fool

'(S)he does have always been a fool.'

Prima facie, this line of analysis would straightforwardly explain both the insertion of the marker de and the presence of the partitive clitic en/ne, which would be the pronominal correlate of the adjective in the core sentence.

However, in the subsequent paragraphs, I will show that, against the traditional view, compelling empirical evidence exists for treating the adjective as non-dislocated. In order to attain this goal, a two-sided strategy will be pursued. On the one hand, emphasis will be put on a comparison of the properties of the adjective in que-exclamatives with respect to that of a real right-dislocated one. On the other hand, the properties of the adjective in queexclamatives will be compared with those of the adjective in the following exclamative construction, which I will label com-exclamative for the sake of reference: ${ }^{6}$

(11) Com és de car aquest vi!

how is of expensive this wine

'How expensive this wine is!'

${ }^{6}$ This construction is also found in Spanish (see Torrego 1994 and Alonso-Cortés 1999):

(i) ¡Cómo es de caro!

how is of expensive

'How expensive it is!'

In Italian and French this task is fulfilled by come/quanto 'how (much)' and comme/combien 'how (much)', respectively (the Italian examples come from Benincà 1995 and the French ones from Gérard 1980):

(ii) a. Come sarà stanco! how will.be tired

'How tired (s)he will be!'

b. Quanto sarà stanco!

how.much will.be tired

'How tired (s)he will be!'

(iii) a. Comme la vie est singulière, changeante!

how the live is singular changeful

'How singular, changeful the life is!'

b. Combien seraient puissants leurs voeux...!

how will.be increasing their voices

'How intensifying their voices will be...!

Benincà points out that (iia) is the normal form in Tuscany and part of Italian central regions, and the form of the standard language, whereas (iib) pertains to Southern Italy and part of the central regions. 
Crucially for our purposes, traditional grammarians haven't argued for the right-dislocated status of the adjective car 'expensive' in com-exclamatives, regardless of the fact that it is introduced by de as well. From the comparison, it will become apparent that no rightdislocation of the adjective is involved in either construction, so that, attractive as it might seem at first sight, the traditional approach cannot withstand a closer scrutiny. Since this point is crucial for an accurate description of the exclamative construction at hand, I will concentrate on it in this section.

\subsection{Informativeness}

Right-dislocates are known to require highly salient reference in the immediate discourse to be licensed (see Vallduví 1990, Villalba 2000):

(12) A: La Maria és molt ingènua.

the Maria is very naïve

B: Ai fill, tu sí que ho ets, d'ingenu! oh son you yes that it-are of-naïve

This requirement for high discourse availability is at the roots of the optionality of the rightdislocate (but see Grosz \& Ziv 1998, Villalba 2000: ch. 3 for qualification), and the infelicity of right-dislocates in out-of-the-blue contexts:

(13) A: La Maria és molt ingènua. the Maria is very naïve 'Mary is very naïve.'

B: Ai fill, tu sí que ho ets i molt(, d'ingenu)! oh son you yes that it-are and much of-naïve 'Oh son, YOU are, certainly.'

[You enter home exultant saying that Prime Minister Aznar has promised that unemployment will disappear in two years]

(14) \#Ai fill, sí que ho ets, d'ingenu! oh son yes that it-are of-naïve 
In contrast with real right-dislocates, the adjective in que-exclamatives is not optional and may appear in out-of-the blue contexts like the one provided in (14), in free alternation with $w h$ - and, more important, com-exclamatives:

(15) a. 'Que n'és!

that of.it-is

b. $\quad{ }^{*}$ Com és! ${ }^{7}$

how is

[You enter home exultant saying that Prime Minister Aznar has promised that unemployment will disappear in two years]

(16) a. Ai fill, que n'ets d'ingenu!

oh son that of.it-are of-naïve

'Man, how naïve you are!'

b. Ai fill, que ingenu que ets!

oh son how naïve that are

c. Ai fill, com ets d'ingenu!

oh son how are of naïve

The contrast directly argues against a unified analysis in terms of right-dislocation of the adjective.

To make the argument even more compelling, consider the fact that right-dislocates, unlike left-dislocates, cannot enter in contrast relations (see Villalba 2000, from which the following example is borrowed):

(17) Hi havia un home i una dona.

'There was a man and a woman.'

${ }^{\#} L i$ van regalar un cotxe, a ell, però $l i$ van comprar un vestit, a ella.

to-him/her gave a car to him but to him/her bought a dress to her

'They gave him a car but they bought her a dress.'

Crucially, the adjective in que-exclamatives can:

\footnotetext{
${ }^{7}$ This sentence is grammatical under the irrelevant interpretation that takes the exclamation as referring to the manner in which someone behaves, paraphrasable as 'The way (s)he is!' 
(18) A: L'Albert va morir atropellat. Quina llàstima, un noi tan eficient! the-Albert died knocked.over what pity a boy so efficient 'Albert was knocked over to death. What a pity, so efficient a fellow.'

B: Pobre nano! Que n'era d'eficient i que n'era de matusser també a vegades! poor fellow that of.it-was of efficient and that of.it-was of ham-handed too to times 'Poor fellow! How efficient he was and how ham-handed he was also sometimes!'

The contrast between (17) and (18) can hardly be explained if we maintain that the adjective is right-dislocated in both instances.

To sum up, the bulk of empirical facts reviewed in this paragraph clearly argues against the claim that the adjective is right-dislocated in que-exclamatives, as far as its informative status is concerned.

\subsection{The position of the adjective}

It is a well-known fact that neutral focus, associated with main stress, marks the limit of the core sentence (see Vallduví 1990, Solà 1990, 1994). This boundary may be made even more precise with the concourse of postfocal tags (the effects of focus projection are dismissed, since they play no role in the discussion):

(19) Ahir va comprar [focus el llibre], [tag collons/tu]!

yesterday him PAST.3 buy the book balls/you

'Yesterday (s)he bought the book, shit/you!'

Note that these tags cannot precede the focus constituent:

(20) *Ahir va comprar [tag collons/tu] [focus el llibre]!

yesterday him PAST. 3 buy balls/you the book

Moreover the material after these tags is typically right-dislocated: ${ }^{8}$

\footnotetext{
${ }^{8}$ The tag may also surface after the right-dislocate without any change in meaning:

(i) El va comprar [focus ahir], [RD el llibre], [tag collons/tu]! him PAST. 3 buy yesterday the book balls/you 
(21) $\mathrm{El}_{1}$ va comprar [focus ahir], [tag collons/tu], [RD el llibre $]_{1}$ !

him PAST.3 buy yesterday balls/you the book

Once we agree that postfocal tags count as a reliable landmark for separating focus and right-dislocates, consider now the behavior of the adjective in que- and com-exclamatives:

(22) a. *Que n'és, collons/tu, de car, aquest vi! that of.it-is balls/you of expensive this wine 'How expensive this wine is, shit/you!'

a'. Que n'és de car, collons/tu, aquest vi! so/that of.it-is of expensive balls/you this wine

b. $\quad$ Com és, collons/tu, de car, aquest vi! how is balls/you of expensive this wine

b'. Com és de car, collons/tu, aquest vi! how is of expensive balls/you this wine

The data are conclusive: the adjective must follow the postfocal tag, which strongly suggests that the adjective car ('expensive') cannot be considered a right-dislocate either in que- or com-exclamatives.

This conclusion also receives empirical support when the interaction of the adjective is considered with respect to clear right-dislocates. It is a well-known fact that right-dislocates may surface in virtually any word order (see Vallduví 1990, Villalba 2000):

(23) a. $\mathrm{N}_{1}{ }^{\prime}$ hi 2 vaig parlar ahir, [amb en Pere $]_{2}$, [del llibre $]_{1}$. of.it-LOC talked yesterday with the Pere of.the book

b. $\mathrm{N}_{1}{ }^{\prime} \mathrm{hi}_{2}$ vaig parlar ahir, [del llibre $]_{1}$, [amb en Pere $]_{2}$. of.it-LOC talked yesterday of.the book with the Pere 
However, the alleged right-dislocated adjective in exclamatives cannot permute with real right-dislocates. Consider the sentences in (24), where the adjective interacts with a clear PP dislocate (as the presence of the resumptive locative clitic hi makes clear):

(24) a. Ai fill, que n'hi van de cansats [RD a l'escola]! alas son that of.it-LOC go of tired to the-school 'Oh son, how tired they attend school!'

b. *Ai fill, que n'hi van [RD a l'escola] de cansats! alas son that of.it-LOC go to the-school of tired

Again, com-exclamatives pattern similarly to que-exclamatives:

(25) a. Ai fill, com hi van de cansats [RD a l'escola]! alas son how LOC go of tired to the-school 'Oh son, how tired they attend school!'

b. *Ai fill, com hi van [RD a l'escola] de cansats! alas son how LOC go to the-school of tired

The conclusion we can draw from the comparison between the sentences in (23) and those in $(24) /(25)$ is that the adjective is not a right-dislocate in neither que-nor com-exclamatives.

\subsection{Patterns of pronominalization}

A second distinctive feature of que-exclamatives is the presence of a partitive clitic en/ne that Solà (1990, 1994, 1999) and Vallduví (1990) consider the clitic correlate of the allegedly right-dislocated adjective. Yet, it has extensively been discussed so far that such an approach cannot be sustained on empirical grounds, as long as the properties of the adjective are taken into account. Furthermore, in this paragraph it will become apparent that the partitive clitic present in que-exclamatives is not fulfilling the same role that a resumptive clitic in rightdislocation structures.

As a point of departure, it must be mentioned that right-dislocated adjectives in Catalan are typically resumed by ho when selected by the copulative verb ser ('be') - in free alternation with en/ne in some cases (see e.g. Solà 1994: ex 40): 
(26) A: És interessant, aquest llibre?

is interesting this book

'Is this book interesting?'

B: No. No ho és particularment, d'interessant.

not not it is particularly of-interesting

'No. It is not PARTICULARLY interesting.'

(27) A: En Pere sembla simpàtic.

the Pere seems friendly

'Pere seems friendly.'

B: Doncs, no ho/n'és gaire, de simpàtic.

well not it/of.it-is any of-friendly

'Well, he isn't ANY friendly.'

Consequently, were the adjectives in the exclamative construction right-dislocated, a similar behavior would be expected. Nevertheless, the prediction reveals itself as incorrect:

(28) a. * Que ho és de car aquest vi!

that it-is of expensive this wine

b. 'Que ho és d'intel-ligent la Maria!

that it-is of intelligent the Maria

Consequently, this sharp empirical pattern concerning pronominalization strongly argues against equating the role of the partitive clitic in que-exclamatives with that of clitics in rightdislocation structures. Therefore, we are reinforced in the conclusion that the adjective in queexclamatives cannot be considered in any event as a right-dislocate.

\section{An Analysis}

All the evidence reviewed in section 2 pointed to the same direction, namely that the adjective in the exclamative construction under discussion is not a right-dislocate. Notwithstanding, this empirically well-sustained position raises two immediate issues:

A) Why does the adjective appear preceded by the marker de ('of')?

B) What is the source of the partitive clitic en/ne? 
Let us firstly consider the issue of marker $d e$.

\subsection{VP-external de}

\subsubsection{The marker de}

One strong argument for considering that que-exclamatives involve a right-dislocated adjective is the presence of $d e$ preceding the adjective. Once it is assumed that this analysis is untenable, a new solution is called for. Prima facie, this empirical problem is aggravated by the fact that Catalan has marker $d e$ in degree modification structures with nouns, but not with adjectives:

(29) a. No té gens * (de) por/pa.

not has any of fear/bread

b. Deixa'm un xic *(de) sal.

lend-me a bit of salt

c. Necessita una mica * $(d e)$ sucre.

needs a bit of sugar

(30) a. Ets molt ( $\left.{ }^{*} d^{\prime}\right)$ intel-ligent.

are much of intelligent

b. Ets massa ( ${ }^{*} d$ ')intel-ligent.

are too.much of intelligent

Notwithstanding several constructions in Catalan show that the presence of marker de is habitual in non-dislocated quantificational structures, which encourage the possibility of abandoning the corelation between marker $d e$ and right-dislocation. ${ }^{9}$ Consider first measure constructions:

(31) a. Aquest llit fa dos metres de llarg.

this bed makes two meters of long

'This bed is two meters long.'

b. Deu fer vint quilos de pes

\footnotetext{
${ }^{9}$ As far as I know, it was Bartra (1986) who firstly suggested a close relationship between quantification, marker $d e$ and the partitive clitic en/ne. 
must make twenty kilos of long

'It must weigh twenty quilos.'

Interestingly, these constructions pattern with que- and com-exclamatives with respect to whsplitting:

(32) a. Quant fa de llarg aquest llit?

how.much makes of long this bed

'How long is this bed?'/‘How long this bed is!'

b. Quant deu fer de pes?

how.much must make of weight

'How much must (s)he weigh?'

As discussed in detail below, this pattern will call for a solution along Kayne's (2002) idea that the marker de is merged outside the VP in similar English and French cases.

Another interesting case is provided by concessive-conditionals, whose structure Quer (1998: 239) explicitly relates to that of com-exclamatives (I respect Quer's glosses and translations, but italics are added to the marker de for the sake of easeness):

(33) a. El posi com el posi de fàcil, estic segur que no aprovaran.

it put.SUB.1SG how it put.SUB.1SG of easy be-1SG sure that not pass.FUT.3PL

'However easy I might put it, I am sure they will not pass.'

b. Vingui com vingui de cansat, anirem a ballar.

come.SUB.3SG how come.SUB.3SG of tired go-out.FUT.1PL to to dance

'However tired he might arrive, we will go out to dance.'

These data suggest that the relevant connection to be established is with quantification structures, rather than with dislocation ones.

When we extend our playground to other Romance languages, instances of quantificational de abound as well. Consider first of all Spanish, which in spite of not inserting, unlike Catalan, a marked de preceding dislocated adjectives (34)a it nevertheless do have com-exclamatives (34)b (see fn. 6): 
(34) a. Juan lo ha sido siempre, $(*$ de) descuidado.

Juan it has been always of careless

b. ¡Cómo és * (de) caro!

how is of expensive

'How expensive it is!'

The dissociation between the presence of $d e$ and right-dislocation is reinforced by the behavior of, so-called, hidden exclamatives (examples from Masullo 1999):

(35) a. ¡Marta es de buena!

Marta is of good

'Marta is so good!'

b. ¡El chico es de travieso!

the boy is of naughty

'The boy is so naughty!'

This construction carries both the factivity character and the scalar implicature associated with overt exclamatives, as the cancellation test makes apparent: ${ }^{10}$

(36) a. ¡Marta es de buena! \#Si es que lo es.

Marta is of good if is that it is

'Marta is so good. If at all.'

b. ¡Marta es de buena! \#Aunque no demasiado.

Marta is of good but not much

'Marta is so good. Even though not that much.'

Obviously, the association of the marker de cannot be established with an allegedly rightdislocated adjective in these cases. ${ }^{11}$

\footnotetext{
${ }^{10}$ As noted in fn. 5, the very existence of this construction challenges the claim made in Zanuttini \& Portner (2001) that the scalar implicature associated with exclamatives is a conventional one deriving from their form and not a conversational one deriving from their content.

${ }^{11}$ A similar conclusion arises from the following intensive construction:

(i) ¡Es feo/caro/malo de cojones! is ugly/expensive/bad of balls

'It is extremely ugly/expensive/bad.'

I leave the analysis of this structure for a future work.

17
} 
Another interesting akin Romance language is Rumanian, which must insert a marker de between the degree modifier and the adjective (after Corver 2000):

(37) a. Ion e extrem *(de) înalt

Ion is extreme of tall

'Ion is extremely tall.'

b. Maria e enorm *(de) fericită.

Maria is enormous of happy

'Maria is enormously happy.'

Furthermore, Rumanian behaves like Catalan and Spanish regarding com-exclamatives, which involve de obligatorily: ${ }^{12}$

(38) Cît e Maria *(de) frumoasă!

how is Maria of beautiful

'How beautiful Maria is!'

In sum, the crosslinguistic perspective clearly points toward a strong relationship between the presence of marker de and quantificational structures, a property that will become paramount in the analysis presented in section 3 .

\subsubsection{Kayne (2002)}

Kayne (2002) considers the case of quantified nominal phrases involving of and de in English and French respectively:

(39) a. John has bought lots of books this year.

b. Jean a acheté beaucoup/peu/trop de livres. Jean has bought lots/little/too(many) of books

\footnotetext{
${ }^{12}$ Rumanian, unlike Catalan, allows the pied-piping version as well:

(i) Cît de frumoasă e Maria! how of beautiful is Maria 'How beautiful is Maria!' 
His proposal crucially relies on Case, specifically on the claim that of/de appears in order to allow the noun to receive case, because the presence of the quantifier blocks assignment from the verb. His proposal fleshes out in the following way for the French sentence (the English one would receive the same analysis): ${ }^{13}$

$\ldots$ [vp acheté [livres peu]] $\rightarrow$ merger of K-de

$\ldots \mathrm{K}-d e$ [vp acheté [livres peu]] $\rightarrow$ movement of livres to Spec,K-de

$\ldots$ [KP livres $\mathrm{K}$ - de [vP acheté $\left[\mathrm{t}_{\mathrm{i}}\right.$ peu] $\left.]\right] \rightarrow$ merger of $d e$

$\ldots$ de $\left[\mathrm{KP}\right.$ livres $_{\mathrm{i}} \mathrm{K}$-de [vP acheté $\left[\mathrm{t}_{\mathrm{i}}\right.$ peu] $\left.]\right] \rightarrow$ movement of VP to Spec,de

$\ldots$ [deP [vP acheté [ $\left.\left.\mathrm{t}_{\mathrm{i}} \mathrm{peu}\right]\right]_{\mathrm{j}}$ de [KP livres $\left.\left._{\mathrm{i}} \mathrm{K}-d e \mathrm{t}_{\mathrm{j}}\right]\right]$

Note that the fact that of/de is merged outside the DP entails that, despite apparences, of/de and the noun do not form a constituent. This move allows Kayne to extend this analysis to quantifier movement in French:

(41) Jean a beaucoup/peu/trop acheté de livres.

Jean has lots/little/too(many) bought of books

According to Kayne, the difference between (39) and (41) consists in that the latter sentence involves a further step:

(42) ... [ $\mathrm{t}_{\mathrm{i}}$ peu $]_{\mathrm{k}}\left[\mathrm{deP}\left[\mathrm{vP} \text { acheté } \mathrm{t}_{\mathrm{k}}\right]_{\mathrm{j}}\right.$ de [KP livres $\left.\left._{\mathrm{i}} \mathrm{K}-d e \mathrm{t}_{\mathrm{j}}\right]\right]$

As he himself remarks (2002: 23):

That remnant movement must come into play here follows from the fact that in the derivation $(199) /(200)$ [= our (40)/(42)] movement of livres to Spec,K-de takes place prior to movement of the phrase containing peu. This in turn reflects the idea that movement to Spec,K-de is a Case-licensing form of movement, that movement of (the phrase containing) peu is a scrambling or focus or quantifier type of movement, and that Case-licensing heads enter the derivation prior to the heads that license scrambling or focus or quantifier movement.

\footnotetext{
${ }^{13}$ Kayne (2002) considers that the very responsible for Case assignment is not of/de itself but a Case agreement head, K-of/de, which is phonologically null in English or French, but overtly realized in languages like German:

(i) mit de- $m$ Mann with the-DAT man 
Crucially for our purposes, this line of reasoning has a strict parallel in Catalan queexclamatives considered in sections 1 and 2 . The next paragraph will develop this resemblance in detail.

\subsubsection{Extending the analysis}

Let us take as a point of departure that que-exclamatives involve a degree modification similar to that of French peu de livres 'few books', with the difference that the modifier is a null degree operator (degOp). Two important points must be considered regarding this assumption. First, the fact that que-exclamatives display island effects, just as com- and whexclamatives do, clearly suggests that some kind of A'-movement is involved. Consider for instance their sensibility to the Coordinate Structure Constraint:

(43) a. *Que n'és de ximple en Pere i una mica intel-ligent la Maria! that of.it-is of fool the Pere and a bit intelligent the Maria

b. *Com és de ximple en Pere i una mica intel-ligent la Maria! how is of fool the Pere and a bit intelligent the Maria

c. *Que ximple que és en Pere i una mica intel·ligent la Maria! how fool that is the Pere and a bit intelligent the Maria

As expected, the sentences become grammatical when the extraction applies across-the-board:

(44) a. Que n'és de ximple en Pere i d'intel-ligent la Maria! that of.it-is of fool the Pere and of-intelligent the Maria

b. Com és de ximple en Pere i d'intel-ligent la Maria! how is of fool the Pere and of-intelligent the Maria

c. Que ximple que és en Pere i d'intel-ligent la Maria! how fool that is the Pere and of-intelligent the Maria

It seems, thus, quite apparent that movement is involved in que-exclamatives. Yet, the motivation for this movement is still to be established. One obvious possibility is feature checking: the null degOp must check its [exclamative] feature against the relevant head in the left periphery. This is the position taken up by Masullo (1999) for Spanish hidden 
exclamatives (see example (35)). Another interesting possibility would be that the movement of the null degOp is triggered to bind the degree variable introduced by the adjective (an idea that has been formulated in several ways since Cresswell 1976; see Zwarts 1992, or GutiérrezRexach 1999 for two different approaches). This line of analysis offers us a straightforward explanation for the restriction noted in 1.2.1 that only gradable adjectives are allowed in queexclamatives (I repeat the examples in (7) for the sake of reference):

(45) a. *Aquest gat és molt persa/quadrúpede.

this cat is very Persian/four-legged

b. 'Que n'és de persa/quadrúpede, aquest gat! that of.it is of Persian/four-legged this cat

c. $\quad$ Que persa/quadrúpede que és aquest gat! that friendly/four-legged that is this cat

Since neither persa nor quadrúpede are gradable adjectives, and consequently do not introduce a degree variable, it can be considered that the illformedness of these sentences is due to whatever general principle is responsible to avoid vacuous quantification.

This line of analysis receives strong empirical confirmation when the following paradigm is considered:

(46) a. Un llibre molt ${ }^{*}$ massa/poc interessant.

a book very too.much/little interesting

b. Que n'és de * massa/ poc interessant aquest llibre! that of.it is of very too.much/little interesting this book

c. Que * massa/poc interessant que és aquest llibre! how very too.much/little interesting that is this book

As shown in (46)a, massa 'too much' is not gradable and it is, hence, incompatible with the degree word molt 'very'. Consequently, although its meaning is one of excess, which is a priori semantically suited for combine with an exclamative construction, the analysis defended in the text that assumes a null degree operator in que-exclamatives offers a plain explanation for the ill-formedness of (46)b in connection with that of (46)c. 
With this much in mind, let us assume that que-exclamatives are derived as Kayne (2002) suggests for French Jean a beaucoup/peu/trop acheté de livres ('Jean has bought lots of/little/too many books.'), so that Que n'és de car! ('How expensive it is!') has the following derivation:

(47)

$\ldots$ [vp és $[$ car degOp]] $\rightarrow$ merger of K-de

$\ldots \mathrm{K}-d e$ [vp és [car degOp]] $\rightarrow$ movement of $c a r$ to $\mathrm{Spec}, \mathrm{K}-d e$

$\ldots$ [KP $\operatorname{car}_{\mathrm{i}} \mathrm{K}-d e$ [vP és $\left[\mathrm{t}_{\mathrm{i}}\right.$ degOp]]] $\rightarrow$ merger of $d e$

$\ldots$ de $\left[\mathrm{KP} \mathrm{car}_{\mathrm{i}} \mathrm{K}-d e\right.$ [vр és [ $\left.\left.\left.\mathrm{t}_{\mathrm{i}} \operatorname{degOp}\right]\right]\right] \rightarrow$ movement of VP to Spec,de

$\ldots\left[\right.$ deP $\left[\mathrm{VP} \text { és }\left[\mathrm{t}_{\mathrm{i}} \operatorname{degOp}\right]\right]_{\mathrm{j}}$ de $\left[\mathrm{KP}\right.$ car $\left.\left._{\mathrm{i}} \mathrm{K}-\mathrm{de} \mathrm{t}_{\mathrm{j}}\right]\right] \rightarrow$ merger of que

$\ldots$ que $\left[\right.$ deP $\left[\mathrm{vP} \text { és }\left[\mathrm{t}_{\mathrm{i}} \operatorname{degOp}\right]\right]_{\mathrm{j}}$ de $\left.\left[\mathrm{KP}_{\mathrm{Car}} \mathrm{car}_{\mathrm{i}} \mathrm{K}-d e \mathrm{t}_{\mathrm{j}}\right]\right] \rightarrow$ movement of degOp to Spec,CP

$\ldots\left[\mathrm{CP}_{\mathrm{CP}}\left[\mathrm{t}_{\mathrm{i}} \operatorname{degOp}\right]_{\mathrm{k}}\right.$ que $\left[\mathrm{deP}\left[\mathrm{VP} \text { és } \mathrm{t}_{\mathrm{k}}\right]_{\mathrm{j}}\right.$ de $\left.\left.\left[\mathrm{KP} \mathrm{car}_{\mathrm{i}} \mathrm{K}-d e \mathrm{t}_{\mathrm{j}}\right]\right]\right]$

The same derivation applies to com-exclamatives straightforwardly: ${ }^{14}$

(48) ... [vp és [car com]] $\rightarrow$ merger of K-de

$\ldots \mathrm{K}-d e$ [vp és [car com] $\rightarrow$ movement of $c a r$ to Spec,K-de

$\ldots\left[\right.$ KP $\operatorname{car}_{\mathrm{i}} \mathrm{K}-d e\left[\mathrm{vP}\right.$ és $\left.\left.\left[\mathrm{t}_{\mathrm{i}} \mathrm{com}\right]\right]\right] \rightarrow$ merger of $d e$

$\ldots$ de $\left[\mathrm{KP}_{\mathrm{P}} \mathrm{car}_{\mathrm{i}} \mathrm{K}-d e\left[\mathrm{VP}\right.\right.$ és $\left.\left.\left[\mathrm{t}_{\mathrm{i}} \mathrm{com}\right]\right]\right] \rightarrow$ movement of VP to Spec,de

$\ldots\left[\right.$ deP $\left[\mathrm{vP} \text { és }\left[\mathrm{t}_{\mathrm{i}} \mathrm{com}\right]\right]_{\mathrm{j}}$ de $\left[\mathrm{KP}\right.$ car $\left.\left._{\mathrm{i}} \mathrm{K}-d e \mathrm{t}_{\mathrm{j}}\right]\right] \rightarrow$ merger of null $\mathrm{C}$

$\ldots \mathrm{C}\left[\mathrm{deP}\left[\mathrm{VP} \text { és }\left[\mathrm{t}_{\mathrm{i}} \mathrm{com}\right]\right]_{\mathrm{j}}\right.$ de [KP car $\left.\left._{\mathrm{i}} \mathrm{K}-d e \mathrm{t}_{\mathrm{j}}\right]\right] \rightarrow$ movement of com to $\mathrm{Spec}, \mathrm{CP}$

$\ldots\left[\mathrm{CP}\left[\mathrm{t}_{\mathrm{i}} \mathrm{com}\right]_{\mathrm{k}} \mathrm{C}\left[\mathrm{deP}\left[\mathrm{vP} \text { és } \mathrm{t}_{\mathrm{k}}\right]_{\mathrm{j}} \mathrm{de}\left[\mathrm{KP}_{\mathrm{Kar}} \mathrm{K}-d e \mathrm{t}_{\mathrm{j}}\right]\right]\right]$

The reward of this line of analysis is twofold. On the one hand, the explanation for the impossibility of a CLLD version of the allegedly right-dislocated adjective:

(49) *De car, que n'és aquest vi!

of expensive that of.it-is this wine

Since $d e$ and the adjective do not form a constituent, the analysis in the text correctly predicts (49) to be impossible altogether.

\footnotetext{
${ }^{14}$ This proposal might extend to Spanish hidden exclamatives in (35). I leave the issue open to further research.
} 
On the other hand, the proposal in the text gives strong empirical support to the generalization raised in Kayne (2002) that the presence of marker de is a necessary condition for wh-splitting. Consider, for instance, the behavior of interrogative quant 'how much' together with that of que- and com-exclamatives:

(50) a. Que n'és *(de) car aquest vi!

that of.it-is of expensive this wine

b. Com és *(de) car aquest vi!

how is of expensive this wine

c. Quant fa *(de) llarg aquest llit?

how makes of long this bed

'How long is this bed?'

d. Quants metres fa *(de) llarg aquest vaixell?

how meters makes of long this ship

'How much meters is this bed long?'

The remaining wrinkle to iron out concerns the contrast between que- and comexclamatives regarding the presence of the partitive clitic. Note that $e n / n e$ is in complementary distribution with overt exclamative operators, such as com ('how'), que ('how') or the emphatic neuter determiner (in substandard Catalan):

(51) a. *Com n'és d'intel-ligent, tu, aquest noi! how of.it-is of-intelligent you this boy

b. 'Que/"Lo intel·ligent que n'és, tu, aquest noi! how/the.NEUT intelligent that of.it-is you this boy

The idea that I would like to propose is that the illformedness of (51) is due to an instance of illicit clitic-doubling, just as (52), for the partitive clitic correlates with the overt exclamative operator:

(52) *A qui el va veure?

to who him saw

'Who did (s)he saw?' 
In contrast, the null exclamative operator must receive its content from the partitive clitic, very much alike to the classical Borer-Jaeggli's analysis of clitics. Hence, the internal structure of the DegP with a null operator would be as follows, following Ordóñez \& Treviño’s (1999) analysis of clitic-doubling:

$$
[\operatorname{DegP}[\operatorname{DegP} O P][\operatorname{Deg},[\operatorname{Deg} e n]]]
$$

As for its derivation, once the VP moves to the Spec,de, the clitic may incorporate to the verb and the null operator may raise to the higher left-periphery, binding the degree variable of the adjective: ${ }^{15}$

$\ldots\left[\right.$ deP $\left[\mathrm{VP}\right.$ és $\left[\mathrm{t}_{\mathrm{i}}[\mathrm{DegP}[\mathrm{DegP} \mathrm{OP}][\mathrm{Deg},[\mathrm{Deg} \text { en }]]]\right]_{\mathrm{j}}$ de $\left.\left[\mathrm{KP}_{\mathrm{Car}} \mathrm{car}_{\mathrm{i}} \mathrm{K}-d e \mathrm{t}_{\mathrm{j}}\right]\right] \rightarrow$ incorporation of the partitive clitic

$\ldots\left[\text { deP }\left[\mathrm{vP} \text { n'és }\left[\mathrm{t}_{\mathrm{i}}\left[\mathrm{DegP}[\operatorname{DegP} \mathrm{OP}]\left[\operatorname{Deg} \text {, [Deg } \mathrm{t}_{\mathrm{k}}\right]\right]\right]\right]\right]_{\mathrm{j}}$ de $\left[\mathrm{KP}\right.$ car $\left.\left._{\mathrm{i}} \mathrm{K}-d e \mathrm{t}_{\mathrm{j}}\right]\right] \rightarrow$ merge of que

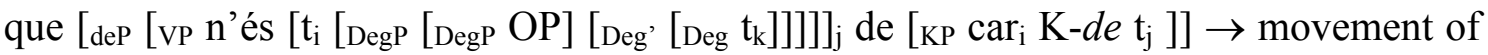
$\operatorname{degOp}$ to Spec,CP

$\ldots\left[\mathrm{CP}[\operatorname{DegP} \mathrm{OP}]_{\mathrm{z}}\right.$ que $\left[\operatorname{deP}\left[\mathrm{VP} \mathrm{n}_{\mathrm{k}}{ }^{\prime} \text { és }\left[\mathrm{t}_{\mathrm{i}}\left[\operatorname{DegP} \mathrm{t}_{\mathrm{z}}\left[\mathrm{Deg},\left[\operatorname{Deg} \mathrm{t}_{\mathrm{k}}\right]\right]\right]\right]\right]_{\mathrm{j}} \mathrm{de}\left[\mathrm{KP}_{\mathrm{Car}} \mathrm{K}-d e \mathrm{t}_{\mathrm{j}}\right]\right]$

In sum, the extension of Kayne's (2002) analysis of de/of as VP-external to que- and com-exclamatives together with the assumption that a null exclamative operator is at stake has turn out highly desirable on both empirical and theoretical grounds, for it offers a straightforward account of the distinctive features of que-and com-exclamatives while maintaining an homogeneous treatment.

\subsection{The complementizer}

The exclamative construction under scrutiny must be introduced by means of the default complementizer que 'that', so that its suppression yields ungrammaticality:

\footnotetext{
${ }^{15}$ It is irrelevant for the analysis whether the movement just involves the operator, as in the text, or the whole DegP containing the trace of the partitive clitic. 
(55) a. Ai, filla, *(que) en vas, d'equivocada!

alas daughter that of.it go. 2 of-mistaken

'Oh, dear, how wrong you are!'

b. *(Que) n'és, de car!

that of.it-is of expensive

'How expensive it is!'

Indeed, the complementizer is preferably found in the rest of exclamative constructions in Catalan, with the exception of com-exclamatives:

(56) a. Ai, filla, que equivocada (que) vas!

alas daughter how mistaken that go.2

'Oh, dear, how wrong you are!'

b. Que car??(que) és!

how expensive that is

'How expensive it is!'

c. Els llibres *(que) té!

the books that has

'How many books he has!'/‘Which books he has!'

(57) Com (*que) és de car!

how that is of expensive

'How expensive it is!'

Nonetheless, traditionally, it has been assumed that the que heading que-exclamatives should not be identified with the complementizer, but with the modifier we find in the equivalent wh-exclamatives in (56)a-b. Against this approach, several arguments may be adduced. Firstly, the que in que-exclamatives is impossible in embedded contexts, in clear contrast with exclamative structures involving a fronted $w h$-element (see also footnote 4 ):

(58) a. *És increïble que n'és de car aquest vi.

is incredible that not of.it-is of expensive this wine

'Its incredible how expensive this wine is.'

b. És increïble que car que és aquest vi. 
is incredible how expensive is this wine

c. És increïble com és de car aquest vi.

is incredible how is of expensive this wine

Were the que a wh-element, this contrast would remain without explanation.

Note furthermore that this behavior has an exact parallel in the interrogative que typical of several Catalan dialects, which is standardly analyzed as a complementizer:

(59) Que vindràs demà?

that will.come tomorrow

'Will you come tomorrow?'

(60) a. *Va preguntar que vindria demà.

asked that would.come tomorrow

'(S)he asked whether (s)he will come tomorrow.'

b. Va preguntar quan vindria.

asked when would.come

'(S)he asked when (s)he will come.'

A second piece of evidence favoring the complementizer analysis can be drawn from the fact that que-exclamatives are always more degraded than com-and wh-exclamatives with respect to extraction from within a clause (partially similar effects are described for Spanish exclamatives by Torrego 1988 and Gutiérrez-Rexach 1999):

(61) a. Que van trobar que n'era d'intel-ligent, la Maria! that found that of.it-was of-intelligent the Maria

b. $\quad$ ?'Com van trobar que era d'intel·ligent, la Maria! how found that was of-intelligent the Maria

c. Que intel-ligent que van trobar que era, la Maria! how intelligent that found that was the Maria

The contrast follows straightforwardly from the proposal in the text if we follow Stowell's (1985) suggestion that null operators cannot properly govern their trace, so that they must be in a strictly local relation with their antecedent. 
An immediate double reward follows from this line of analysis, for on the one hand, it allows us to discard the very existence of a unique unstressed wh-element in the paradigm, and on the other hand, it permits a more homogeneous treatment of elements surfacing in the left periphery of Catalan sentence, which is, in any event, a desirable outcome.

\section{Conclusion}

The main hypothesis of this paper is that certain exclamative constructions apparently involving the right-dislocation of an adjective should be analyzed as having it in situ, and involving a null exclamative degree operator. First of all, several standard tests have been conducted to confirm that que-exclamatives are fully-fledged exclamative sentences, and not just declarative sentences expressing an exclamation.

The second concern has been offering a fine-grained characterization of the construction, specifically of the introduction of the sentence by means of complementizer que 'that', the presence of the partitive clitic en/ne, and the introduction of the adjective by means of the marker de ('of'). Evidence has been provided that traditional analysis are incapable of offering a principled explanation of these properties, particularly once com-exclamatives enter the playground.

Finally, an analysis of que-exclamatives has been offered deriving the exclamative character of the construction from the presence of a null exclamative operator. Moreover, it has been argued that this construction involves a VP-external de, along the lines of Kayne's (2002) analysis of English preposition of and its French counterpart de. When combined, these two aspects have offered a principled and unified explanation for both que- and comexclamatives.

\section{References}

Alonso-Cortés, Ángel. 1999. «Las construcciones exclamativas. La interjección y las expresiones vocativas». In Ignacio Bosque; Violeta Demonte. ed. Gramática descriptiva de la lengua española. Vol. III. Madrid: Espasa. 3993-4050.

Bartra, Anna. 1986. Encara n'hi ha més (entorn de en i alguns SN genitius). Llengua \& Literatura 2: 377-427.

Corver, Norbert. 2000. Degree adverbs as displaced predicates. Rivista di linguistica 12: 155191. 
Cresswell, Maxwell J. 1976. The semantics of degree. In Barbara H. Partee. ed. Montague Grammar. New York: Academic Press. 261-292.

Espinal, M. Teresa. 1997. Non-Negative Negation and Wh-Exclamatives. In D. Forget; Paul Hirschbühler; France Martineau; María Luisa Rivero. ed. Negation and Polarity: Syntax and Semantics. Selected Papers from the Colloquium Negation: Syntax and Semantics. Amsterdam/Philadelphia: John Benjamins. 75.93.

Gérard-Naef, Josselyne 1980 L'Exclamation en français la syntaxe des phrases et des expressions exclamatives. Tübingen: Max Niemeyer.

Grosz, Barbara; Ziv, Yael. 1998. Centering, Global Focus, and Right Dislocation. In M. Walker; A. Joshi; E. Prince. eds. Centering in Discourse. Oxford: Oxford University Press. 39-51.

Gutiérrez-Rexach, Javier. 1999. The structure and interpretation of Spanish degree neuter constructions. Lingua 109: 35-63.

Kadmon, Norit; Fred Landman. 1993. Any. Linguistics and Philosphy 15: 353-422.

Kayne, Richard. 2000. Parameters and Universals. Oxford/New York: Oxford University Press.

Kayne, Richard. 2002. On Some Prepositions that Look DP-Internal: English of and French de. ms. New York University.

López del Castillo, Lluís. 1999 Gramàtica del català actual. Barcelona: Ed. 62.

Mariner, Sebastià. 1979. «Si que... (\# sí que...), sorpresivo-encarecedor en catalán». In: Estudios ofrecidos a Emilio Alarcos Llorach, IV. Oviedo: Servicio de Publicaciones de la Universidad de Oviedo. 167-179.

Milner, Jean-Claude. 1978. De la syntaxe à l'interprétation. Paris: Seuil.

Ordóñez, Francisco; Treviño, Estela. 1999. Left dislocated subjects and the pro-drop parameter: A case study of Spanish. Lingua 107: 39-68.

Radford, Andrew. 1982. The syntax of WH-exclamatives in Italian. In Nigel Vincent; Martin Harris. eds. Studies in the Romance Verb. London: Croom Helm. 185-204.

Solà, Joan. 1990. L'ordre de mots en català. Notes pràctiques. In his Lingüística i normativa. Barcelona: Empúries. 91-125.

Solà, Joan. 1994. Els pronoms febles. In his Sintaxi normativa: estat de la qüestió. Barcelona: Empúries. 39-70.

Solà, Joan. 1999. Si que és car. In his Parlem-ne. Converses lingüístiques. Barcelona: Proa. 
Torrego, Esther. 1994. Cómo. In V. Demonte ed. Gramática del español. México D.F.: El Colegio de México. 255-266.

Torrego, Esther. 1988. Operadores en las exclamativas con artículo determinado de valor cuantitativo. Nueva Revista de Filología Hispánica XXXVI: 109-122.

Vallduví, Enric. 1990. The informational component. University of Pennsylvania. PhD Thesis.

Villalba, Xavier. 2000. The syntax of sentence periphery. Universitat Autònoma de Barcelona. PhD Thesis.

Wheeler, Max; Yates, Alan; Dols, Nicolau. 1999 Catalan. A comprehensive grammar. Londres/New York: Routledge.

Zanuttini, Raffaella; Portner, Paul. 2000. The characterization of exclamative clauses in Padovan. Language 76: 123-132.

Zanuttini, Raffaella; Portner, Paul. 2001. Exclamative Clauses at the Syntax-Semantics Interface. ms. Georgetown University.

Zwarts, Joost. 1992. X' Syntax-X' Semantics. OTS: PhD Dissertation. 